\title{
REDESCRIPTION OF THREE CALIGID SPECIES OF THE GENUS Caligus Müller, 1785 (Copepoda: Caligidae), PARASITES OF MARINE FISH Decapterus sp. (Perciformes: Carangidae) FROM TONKIN GULF, VIETNAM
}

\author{
Kazachenko V. N. ${ }^{1}$, Kovaleva N. N. ${ }^{1}$, Ha Duy Ngo ${ }^{2}$, \\ Nguyen Van $\mathrm{Ha}^{2}$, Nguyen Vu Thanh ${ }^{2} *$ \\ ${ }^{1}$ Far Eastern State Technical Fisheries University, Vladivostok, Russia \\ ${ }^{2}$ Institute of Ecology and Biological Resources, VAST, *nvthanh49@yahoo.com
}

\begin{abstract}
So far, parasitic copepods belonging to the family Caligidae on marine fishes in Vietnam have been poorly studied. At present, 250 copepods species belong to the genus Caligus have been registrated in the world, including 54 species recognized in waters of the South East Asia region and 11 species recorded from Vietnam. Based on the specimens of parasite copepods found on the marine fish Decapterus sp. which were collected by scientific researchers of TINRO, Vladivostok Russia from Tonkin gulf, Vietnam in 1960-1961, a re-description of three species of the genus Caligus, viz. Caligus confusus Pillai, 1961, C. constrictus Heller, 1865 and C. robustus Bassett-Smith, 1898 is given. The hosts, distribution and key to the eleven Caligus species for Vietnamese fauna are also provided herein.
\end{abstract}

Keywords: Caligus, copepods, marine fish, Tonkin gulf, Vietnam.

\section{INTRODUCTION}

The fauna of parasitic copepods of marine fishes in Vietnam is poorly studied. Recently, a few of papers have been published so far (Arthur \& Te, 2006 [1]; Vo et al., 2008 [18]; Samotylova, 2010 [11, 12]; Samotylova et al., 2011 [13]; Samotylova et al., 2012 [14, 15] and Kazachenko et al., 2013 [7]). In this paper, the morphological characteristics, distribution and redescription of three parasitic copepod species, viz. Caligus confusus, C. constrictus and $C$. robustus registered in fish species of the genus Decapterus (Perciformes, Carangidae) are reported.

\section{MATERIALS AND METHODS}

All the materials of this sudy was collected during 1960-1961 years in several expeditons conducted by the Laboratory of Parasitology of the Pacific Scientific Research Fisheries Center (TINRO), Vladivostok in the bilateral scientific collaboration program signed between the Vietnam Government and the Government of the USSR, for studying the marine biological resources of Vietnam and collecting parasitic helminthes and copepods on marine fishes in the Tonkin gulf, Vietnam. The specimens of copepods were kept at the TINRO, Vladivostok.
Collection and processing of these materials were done following Bykhovskaya-Pavlovskaya (1985) [2] method and all measurements of copepods are given in millimetre.

\section{RESULTS AND DISSCUSION}

\section{Caligus confusus Pillai, 1961 (Figs 1-14)}

Syn.: C. alalongae (nec. Krøyer, 1863) of Kirtisinghe, 1937 and Yamaguti, 1954; C. constrictus (nec. Heller, 1865) of Wilson, 1937 and Shiino, 1959.

Host: Decapterus sp. (Perciformes, Carangidae).

Organ localization: gills.

Intensity and prevalence: 2-6 specimens from 2 of the 60 examined fish (3.3\%).

\section{Description}

Females. Caligoid body form (fig. 1). Female $(\mathrm{n}=6), \quad \mathrm{L}=3.30-4.04 \quad$ (3.53) $\mathrm{mm}$. Cephalothorax broad, flattened, fringed by edge membrane. Frontal plates developed fairly well, with widely spaced lunules on them. The structure consists of a cephalothorax first to third thoracic segments. The fourth thoracic segment free, narrowed. Genital complex consists of two parts with convex lateral edges. 
The first part in the form of a neck, a second one with a tapered front part, the lateral edges parallel to each other. Post lateral corners rounded, slightly protruded backward, the posterior edge of genital complex formed in a notch to which 1-segmented abdomen is attached (fig. 1). Abdomen small, one-segment, narrowed proximally (fig. 13). Uropods small (fig. 14) have four large plumose setae, two small plumose setae and one naked seta. Eggs sacs are cylindrical, uniseriate. The first antenna 2-segmented, basal segment with plumose setae, the second segment long. Second antenna 3segmented (fig. 2). The distal segment of the second antenna a curved claw, with two spines on the ventral surface of the proximal part of the

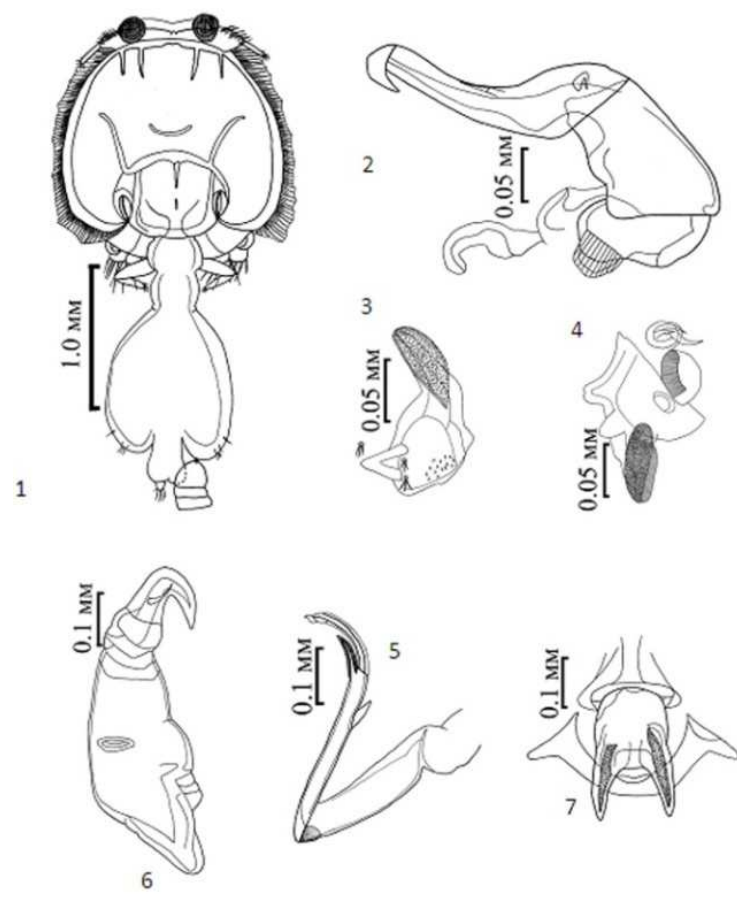

claw. Postantennal apophysis (fig. 3) with an oval base has a large apophysis with the oval distal end. A little extra sensitive apophysis is at the opposite end of the base and its distal end is pointed; there are three papillae provided with hairs. First maxilla 1-branched (fig. 4), there are two blunt apophysis, at its base is a papilla with three naked setae. Second maxilla twosegmented (fig. 5) and branchiform, at the distal end has two unequal plumose setae, distal part of one of them twisted into a spiral. Maxilliped 3-segmented (fig. 6), at the base of the distal joint is a naked seta. Sternal furca with an oval base and two parallel branches, distal parts of branches thin down (fig. 7).

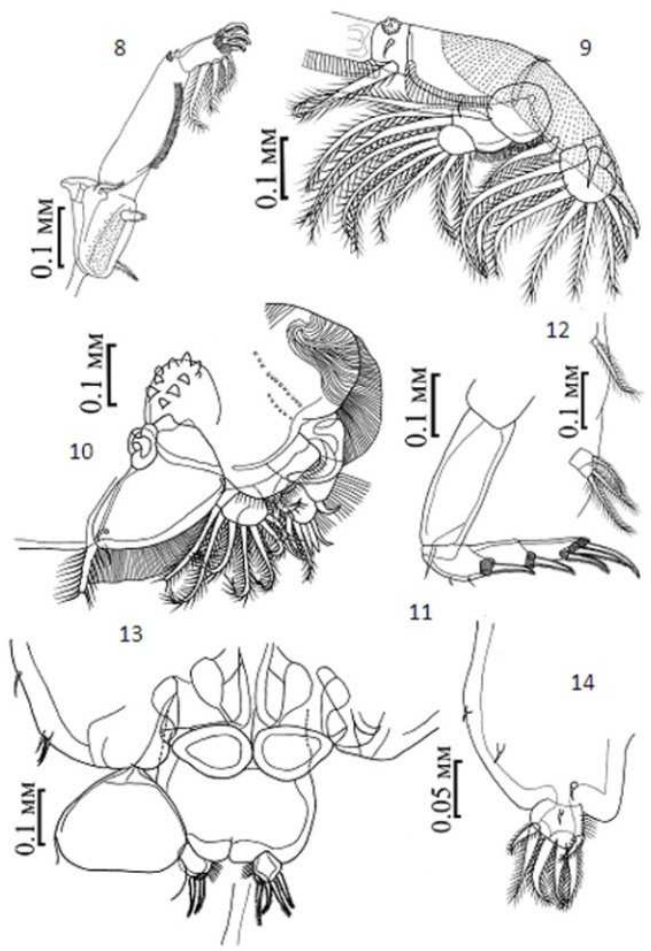

Figure 1-14. Caligus confusus, females: 1. Dorsal view; 2. Second antenna; 3. Postantennal apophysis; 4. First maxilla; 5. Second maxilla, 6. Maxilliped 7. Sternal furca; 8. Leg 1; 9. Leg 2; 10. Leg 3; 11. Leg 4; 12. Legs 5 and 6; 13. Abdomen and caudal rami; 14. Caudal ramus.

Leg 1. Two-segmented (fig. 8), the reduced endopodite as a small outgrowth and at the distal end has two naked spines; protopodite on the outside corner has a small plumose seta, proximal to the inner margin carries a small plumose seta. Exopodite two-segmented, the inner edge of the first segment feathered, a small bristle seta located at the distal outer corner. The inner edge of the second segment bears 3 plumose setae, their length decreases from the proximal to the distal end. Three spines disposed terminally, one of these spines 
is uncleave, two of them in the form of claws. No plumose seta with medium length located at the base of the inner claw.

Leg 2. Two branches (fig. 9). The branches of the second swimming legs 3-segmented, interpodal plate plumose. The outer edge of basipodite plumose, on the inner edge has small naked seta, proximal has large plumose seta, and at the distal outer corner is a naked seta, and at the proximal end is a small papilla and another naked seta. The outer edge of the first segment of the exopodite feathered, on the outer distal angle is a spinule with the membrane at the base, the inner edge bears a plumose seta. The second segment of the exopodite has a small spine at the distal outer edge, on the internal edge is a plumose seta. The third segment of the exopodite carries 5 plumose setae, one seta has plumage at the inner edge, and on the other side of the seta is a membrane, at the outer corner is a small thorn. The length of the seta increases from the outer to the inner edge. The first and second segments of the endopodite are plumose on the outer edge of the first segment on the inner edge has one, and the second - two plumose setae, the distal segment is 6 plumose setae.

Table 1. Hosts and distribution of Caligus confusus Pillai, 1961

\begin{tabular}{|c|c|c|c|}
\hline \multicolumn{2}{|c|}{ Host } & \multirow{2}{*}{ Region } & \multirow{2}{*}{ Author } \\
\hline Species & Family & & \\
\hline $\begin{array}{l}\text { Alepes djedaba } \\
(=\text { Caranx djedaba) }\end{array}$ & Carangidae & South Africa & After Ho, Lin, 2004 \\
\hline $\begin{array}{l}\text { Alepes djedaba } \\
(=\text { Caranx kalla) }\end{array}$ & Carangidae & $\begin{array}{l}\text { Sri Lanka, South } \\
\text { China Sea }\end{array}$ & $\begin{array}{l}\text { Kirtisinghe, 1937; } \\
\text { Song, Chen, } 1976\end{array}$ \\
\hline Caranx hippos & Carangidae & $\begin{array}{l}\text { Panama (Pacific coast), } \\
\text { Ecuador, Galapagos Islands }\end{array}$ & Wilson, 1937 \\
\hline Caranx ignobilis & Carangidae & Taiwan & Ho, Lin, 2004 \\
\hline C. melampygus & Carangidae & Taiwan, Eniwetok atoll & $\begin{array}{l}\text { Lewis, 1968; Ho, Lin, } \\
2004\end{array}$ \\
\hline $\begin{array}{l}\text { C. heberi }(=C \text {. } \\
\text { sansum) }\end{array}$ & Carangidae & $\begin{array}{l}\text { India, South Indian ocean, } \\
\text { Sri Lanka }\end{array}$ & $\begin{array}{l}\text { Kirtisinghe, 1937, 1964; } \\
\text { Pillai, } 1961\end{array}$ \\
\hline C. sexfasciatus & Carangidae & Taiwan, south Africa & Ho, Lin, 2004 \\
\hline Caranx sp. & Carangidae & $\begin{array}{l}\text { New Caledonia, Sri Lanka, } \\
\text { Celebes }\end{array}$ & $\begin{array}{l}\text { Kirtisinghe, 1937; Yamaguti, } \\
\text { 1954; Kabata, } 1968\end{array}$ \\
\hline Elagatis bipinnulata & Carangidae & $\begin{array}{l}\text { Taiwan, Indian ocean, } \\
\text { Panama (Pacific coast) }\end{array}$ & $\begin{array}{l}\text { Wilson, 1937; Lewis et } \\
\text { al., 1969; Ho, Lin, } 2004\end{array}$ \\
\hline Elagatis sp. & Carangidae & Celebes & Yamaguti, 1954 \\
\hline Seriola dumerili & Carangidae & Taiwan & Ho, Lin, 2004 \\
\hline Seriola sp. & Carangidae & Colombia(Pacific coast) & Shiino, 1959 \\
\hline Decapterus sp. & Carangidae & Vietnam & Present paper \\
\hline Coryphaena hippurus & Coryphaenidae & Panama (Pacific coast) & Wilson, 1937 \\
\hline Epinephelu stauvina & Serranidae & Kuwait & After Ho, Lin, 2004 \\
\hline Rhabdosar gusholubi & Sparidae & South Africa & After Ho, Lin, 2004 \\
\hline
\end{tabular}

Leg 3. Two branches (fig. 10), branches are 2-segmented, basal claw strongly bent. Interpodal plate plumose. The outer edge of apron plumose, covered with wavy grooves. The inner edge of the apron, near the center, having the protruded wary, equipped with large spikes and branched apophysis outgrowth obtused end. At the base of the basal claw exopodite are two rows of spinules. The first segment of the exopodite bears long setae and at the outerside has a naked thornon. The second segment has three naked and five plumose setae of different sizes. The first segment of the endopodite has a plumose seta on the inner side. Second segment of endopodite has six plumose setae. 
Leg 4. Uniramous, 3-segmented (fig. 11). Five thorns of the exopodite at the base have plumage. The size of the thorns on the distal segment increases from the outside to the inside. The first segment of the fourth swimming leg bears proximally two naked setae. On the outer distal angle of the protopoditeis a naked seta.

Leg 5. Rudimentary (fig. 12), located on the postventral corners of the genital complex, consists of a single bristle.

Leg 6. Rudimentary (fig. 12), represented by three setae, located on postventral corners of the genital complex.

Males. Unknown.

\section{Remarks}

Caligus confusus erected by Pillai (1961) is a specific parasite of fish species of the family Carangidae and common in the Indian and Pacific Oceans, but rarely found in fish species of the families Coryphaenidae, Serranidae and Sparidae, and the hosts and distribution of C. confuses are shown in table 1 .

Caligus constrictus Heller, 1865 (Figs 15-31)

Syn: Midiascarangis Rangnekar, 1956; C. constrictus (nec. Heller, 1865) of Wilson, 1937 and Shiino, 1959.

Host: Decapterus sp. (Perciformes, Carangidae).

Organ localization: gills.

Intensity and prevalence: 4-6 specimens from 2 of the 60 examined fish $(3.3 \%)$.

Females. Caligoid body form (fig. 15). Female $(n=4)$, length 2.52-3.08 (2.80) mm. Cephalothorax rounded, flattened, marginal membranes present. Frontal plates well developed, with widely spaced lunules on them. Cephalothorax comprises first-third thoracic segments. The fourth thoracic segment free, short and narrow. Genital complex large, extended to the rear end and a shallow notch on the posterior edge. The front part is tapered with parallel lateral edges. Genital complex is longer than the width. Abdomen small, one-segment, extended proximally (fig. 23). Caudal ramous small (fig. 31), has four large plumose setae, two small plumose and one naked seta. Egg sacs are cylindrical, eggs uniseriate. The first antenna 2-segmented (fig. 16), the basal segment with a plumose setae, the second segment long. Antenna 3-segmented (fig. 17). The distal segment of the second antenna with claw, bearing two small setae at both basal and middle regions. Postantennal apophysis (fig. 18) has oval base with two apophysis. Large apophysis blunt and little apophysis acute. There are three papillae with hairs. First maxilla 1-branched (fig. 19) with a wide base, at its base is a papilla with three naked setae of different sizes, distal process acute bent on the inner side,carries a thornon the outer side. The second maxilla two-segmented (fig. 20) has two unequal plumose spinesat the distal end, one of them twisted into a spiralat the distal part. Maxilliped 3-segmented (fig. 21), at the base of the distal joint of a naked seta. Sternal furca with oval base and two slightly inward curved branches, distal branches acute (fig. 22).

Leg 1. Two-segmented (fig. 24), the reduced endopodite as a small apophysis, carries two naked spinesat the distal end; protopodite has a small plumose setaon the outside corner, carries a small plumose seta at the inner margin. Exopodite 2-segmented, the inner edge of the first segment plumose, at the distal outer corner is a small bristle. The second segment on the inner edge has three plumose setae, their length decreases from the proximal to the distal edge. Three thorns located terminally, one of these thorn unsegregated, two as segregated chela distally. Small naked seta located at the base of the inner thorn.

Leg 2. Two branches (fig. 25). The branches of the second swimming legs 3-segmented, interpodal plate plumose. The outer edge of basipodite plumosed, on the its inner edge located small naked seta, on the proximal part located large plumose seta. At the distal outer corner located one naked seta, and at its proximal located small naked seta. The outer edge of the first segment of the exopodite plumose, on the outer distal angle is a spinule with the membrane at the base, on the inner edge is a plumose seta. The second segment of the exopodite has a small spine at the distal outer 
edge anda plumose seta on the inner edge. The third segment of the exopodite carries five plumose setae, one seta at the inner edge is plumose, and on the other side this seta has a membrane and a spine covered with small bristles. The length of the setae increases from the outer to the inner edge. On the outer corner of the distal segment is a small spike. The first and second segments of the endopodite are plumose on the outer edge, the first segment on the inner edge has one, and the second two plumose setae, the distal segment has 6 plumose setae.
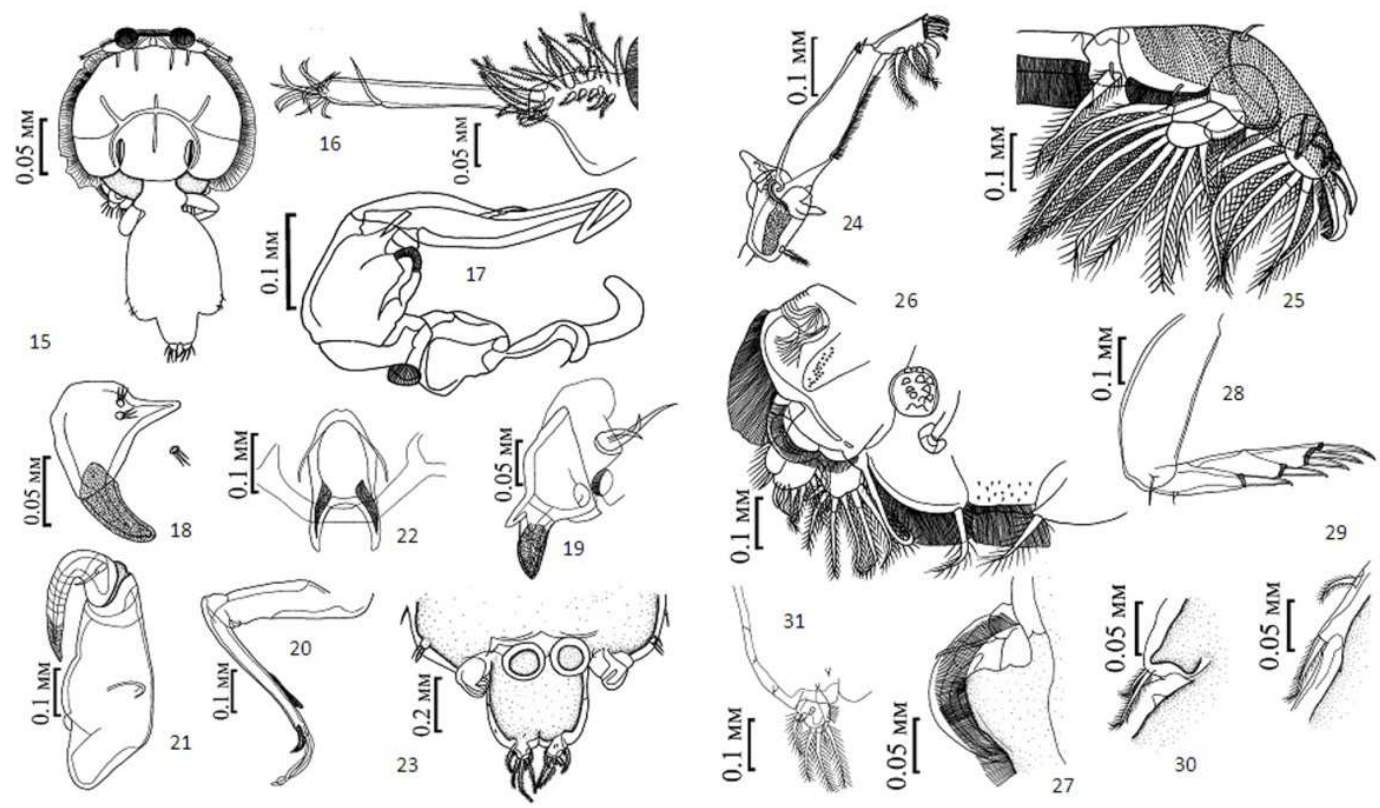

Figure 15-31. Caligus constrictus, females:15. Dorsal view; 16. First antenna; 17. Second antenna; 18. Postantennal apophysis; 19. First maxilla; 20. Second maxilla; 21. Maxilliped; 22. Sternal furca; 23. Abdomen and caudal rami; 24. Leg 1; 25. Leg 2; 26. Leg 3; 27. Basal claw leg 3; 28. Leg 4; 29. Legs 5 and 6; 30. Leg 6, 31. Caudal ramus.

Leg 3. Two branches (fig. 26), branches 2segmented, basal claw strongly bent. Interpodal plate plumose. The outer edge of apron plumose and corrugated. The inner edge of the apron, near the center, having the protruded wary, equipped with large spikes and branched apophysis outgrowth obtused end. The first segment of the exopodite on the outside has a naked thorn and long setae. The second segment has three naked and five plumose setae of different sizes, the outer edge is covered with long setae. The first segment of the endopodite has plumose seta on the inner side. Six plumose setae are disposed on the second endopodite, the outer edge is covered with setae.

Leg 4. Uniramous, 3-segmented (fig. 27). Five thorns at the base of the exopodite plumosed. The size of the distal joint of thorns increases from the outside to the inside. The first segment of the fourth swimming leg has a naked proximal seta. Protopodite has plumose setaon the outer distal angle.

Leg 5. Rudiment (fig. 29) and located on the postventral corners of the genital complex, consists of a single seta.

Leg 6. Rudiment (fig. 30) and located on the postventral genital corners of the genital complex, which represented by two setae.

\section{Remarks}

Caligus constrictus Heller, 1865 is a specific parasite of fish species of tht family Carangidae and common in the Indian and 
Eastern Pacific Oceans, but rarely found on fish species of the family Stromateidae, and the hosts and distribution of $C$. constrictus are given in table 2 .

Table 2. Hosts and distribution of Caligus constrictus Heller, 1865

\begin{tabular}{|c|c|c|c|}
\hline \multicolumn{2}{|c|}{ Host } & \multirow{2}{*}{ Region } & \multirow{2}{*}{ Author } \\
\hline Species & Family & & \\
\hline Alectis indicus & Carangidae & Sri Lanka & Kirtisinghe, 1956, 1964 \\
\hline Carangoides malabaricus & Carangidae & India & Pillai, 1961 \\
\hline C. chrysophrys & Carangidae & India & Rangnekar, 1956 \\
\hline Caranx nigriscens & Carangidae & India & Rangnekar, 1956 \\
\hline Decapterus sp. & Carangidae & Vietnam & Present paper \\
\hline Stromateus sp. & Stromateidae & Indian Ocean & Heller, 1865 \\
\hline
\end{tabular}

Caligus robustus Bassett-Smith, 1898 (Figs 3245)

Host: Decapterus sp. (Perciformes, Carangidae).

Organ localization: gills.

Intensity and prevalence: 1 female and 1 male from 1 out of 60 fish examined (1.7\%).

Female. Caligoid body form (fig. 32). Female $(\mathrm{n}=1)$, the length of $5.47 \mathrm{~mm}$. The cephalothorax is broad and flattened, length equal to the width. Marginal membranes with fairly deep rear notches. Frontal plates well developed, lunules present. First-third thoracic segments comprise the thorax. The fourth thoracic segment free, narrow. Genital complex heart-shaped, tapering to anterior end. Postlateral corners rounded, posterior margin arcuate notch. Abdomen long, two-segment, the boundaries between segments are expressed well. The first segment slightly longer than the second, the distal portion of the second segment narrowed. Caudal branch short, wide (fig. 45), bears four large and two small plumose setae. The inner edge of the caudal branches covered with small setae. Egg sacs cylindrical, eggs uniseriate.

The first antenna 2-segmented, basal segment with a plumose setae, second segment small. Antenna 3-segmented (fig. 33), distal segment of the second antenna a curved claw. The ventral side of the proximal part of the claw with two spinules. Postantennalapophysisuncinate, at the base are two papillae provided with hairs, another papilla situated near apophysis. First maxilla 2- segmented (fig. 34), at its base a papilla with three naked setae. Second maxilla two-segmented (fig. 35), two unequal spines situated at distal end. Maxilliped 3-segmented as subchela (fig. 36), a naked seta at the base of the distal segment. Basal segment maxilliped has two proecting small and large tooth-like apophysis in myxsal area. Sternal furca with rectangular base with two slightly curved wide, bordered branches, distal ends of branches oval (fig. 37).

Leg 1. Two-segmented (fig. 39), the reduced endopodite in the form of a small apophysis at the distal end, it carries one naked thorn. Protopodite proximally has small plumose seta on the outer corner and small naked seta on the inner proximal part. Exopodite 2-segmented, first segment on inner edge has plumage, at the distal outer corner is a small spine seta. 3plumose setae are attached to the inner edge of the second segment, their length decreases from the proximal to the distal edge end. Three spines are located terminally.

Leg 2. Two branches (fig. 40). The branches of the second swimming legs 3-segmented. Interpodal plate and the outer edge of the basipodite feathered. The inner edge of basipodite has a small naked seta, at the its proximal - large plumose seta. At the distal outer corner located naked seta, and at the proximal part located small naked seta. First segment of the exopodite on the outer distal angle has a spinule with the membrane at the base, on the inner edge there is a plumose seta, the outer edge is feathered. Small spines are on 
the distal outer edge of the second segment of the exopodite, on the inner side is a plumose seta. Five plumose setaeare on the third segment of the exopodite, the length of which increases from the outer to the inneredge, one side of the bristle at the inner edge is plumose, and on the other side is a membrane and two spines covered with small hairs. The outer edge of the first-third segments of the endopodite is covered with small hairs. The first segment on the inner edge has one, the second has two plumose setae, the third segment has 6 plumose setae.
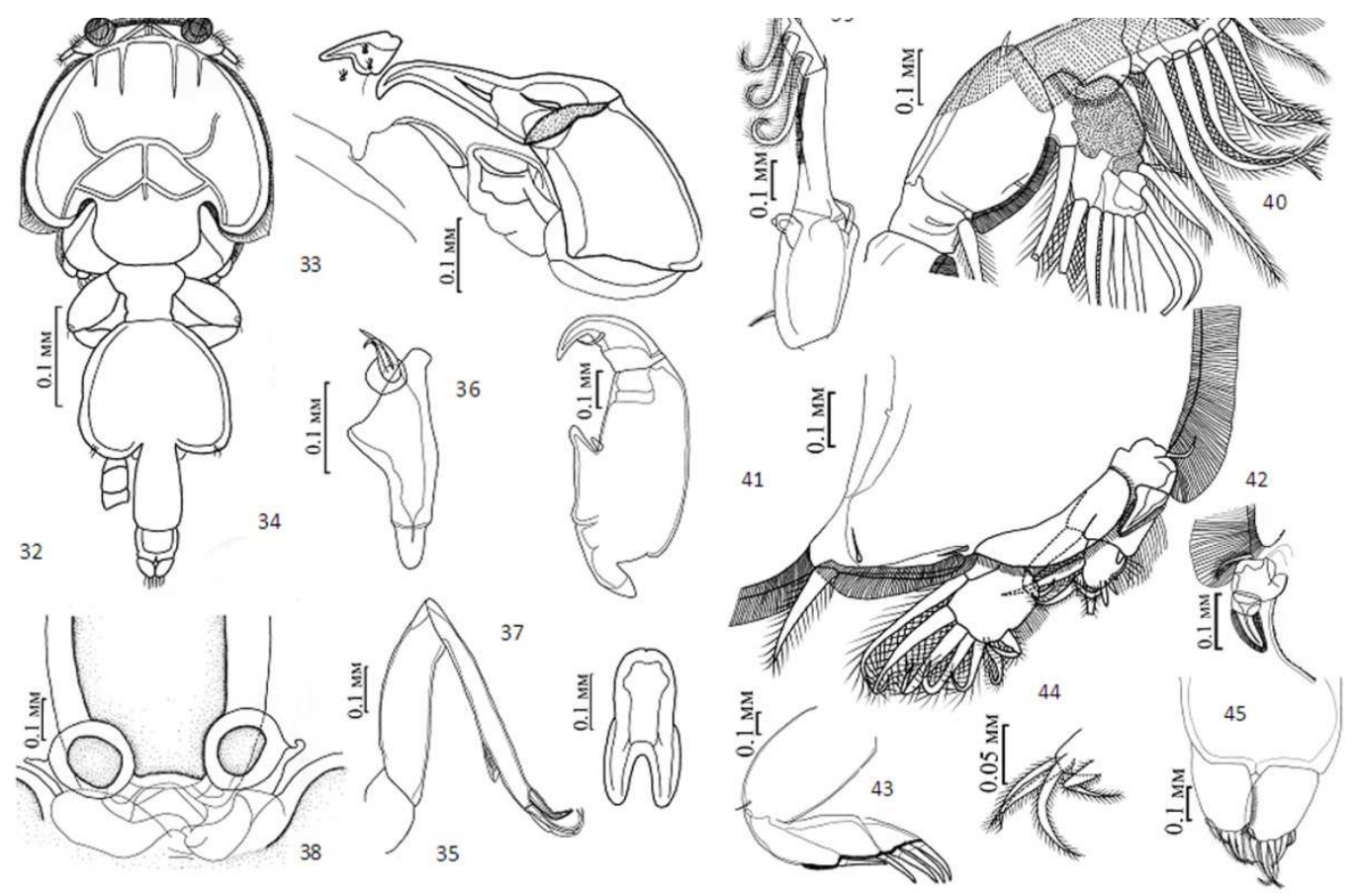

Figure 32-45. Caligus robustus, females: 32. Dorsal view; 33. Second antenna; 34. First maxilla; 35. Second maxilla; 36. Maxilliped; 37. Sternal furca; 38. Spermatophores; 39. Leg 1; 40. Leg 2; 41. Leg $3 ; 42$. Basal claw leg $3 ; 43$. Leg $4 ; 44$. The fifth swim leg 5 and 6; 45. Caudal rami.

Leg 3. Two branches (fig. 41), twosegmented branches, interpodal plate plumose. Naked papillae with setae arelocatedon the first outside segment of the exopodite,on the inner side there is a large seta. The outer edge of the second segment covered by bristles, with three naked and five plumose setae of different sizes. On the inside of the first segment of endopodite there is one seta, the second segment has six plumose setae. Apron from the outer side is plumose, basal claw small (fig. 42).

Leg 4. Uniramous (fig. 43), 3-segmented and wide. Five thorns of exopodite plumosed at the base. Protopodite on the outer distal angle bearring seta.

Leg 5 and 6. Rudiments (fig. 44) and located on the postventral corners of the genital complex, consists of four setae.

\section{Remarks}

Caligus robustus Bassett-Smith, 1898 is widely distributed in the Indian, Atlantic and Pacific Oceans, this species is a specific parasite of fishes of the family Carangidae, but rarely found in fishes of the families Scombridae, Lutjanidae and Haemulidae, and the hosts and distribution of $C$. robustusare are shown in table 3 .

Discussion. These fishes, which were investigated belonging to the genus Decapterus, are new hosts for Caligus constrictus, $C$. robustus and $C$. confusus. All of the three species Caligus constrictus, $C$. robustus and 
C. confusus are firstly recorded for the fauna of Vietnam. The re-description herein added more details to the previous description of these three species.

Table 3. Hosts and distribution of Caligus robsutus Bassett-Smith, 1898

\begin{tabular}{|c|c|c|c|}
\hline \multicolumn{2}{|l|}{ Host } & \multirow{2}{*}{ Region } & \multirow{2}{*}{ Author } \\
\hline Species & Family & & \\
\hline Alectis sp. & Carangidae & Philippines, Sulawesi & Cressey, 1991 \\
\hline $\begin{array}{l}\text { Alepes djedaba }(=\text { Caranx } \\
\text { djedaba }=\text { Atule djedaba })\end{array}$ & Carangidae & $\begin{array}{l}\text { Trincomalee (Sri } \\
\text { Lanka) }\end{array}$ & $\begin{array}{l}\text { Bassett-Smith, 1898; } \\
\text { Kirtisinghe, } 1964\end{array}$ \\
\hline $\begin{array}{l}\text { Atute mate }(=\text { Caranx affinis } \\
=\text { Selar } \text { mate) }\end{array}$ & Carangidae & $\begin{array}{l}\text { Trincomalee } \\
\text { (Sri Lanka) }\end{array}$ & $\begin{array}{l}\text { Bassett-Smith, 1898; } \\
\text { Kirtisinghe, } 1964\end{array}$ \\
\hline $\begin{array}{l}\text { Caranx crysos } \\
\text { (=Carangoides crysos } \\
=\text { Paratrachurus crysos) }\end{array}$ & Carangidae & $\begin{array}{l}\text { Gulf of Mexico, } \\
\text { Jamaica, Belize }\end{array}$ & $\begin{array}{l}\text { Wilson, 1913; Bere, } \\
\text { 1936; Cressey, } 1991\end{array}$ \\
\hline $\begin{array}{l}\text { C. bartholomaei } \\
\text { (=Carangoides bartholomaei) }\end{array}$ & Carangidae & Belize & Cressey, 1991 \\
\hline C. hippos & Carangidae & $\begin{array}{l}\text { Texas, Jamaica, } \\
\text { Gulf of Mexico, } \\
\text { Mauritania }\end{array}$ & $\begin{array}{l}\text { Wilson, 1913; Bere, } \\
\text { 1936; Causey, 1953; } \\
\text { Cressey, Nutter, 1987; } \\
\text { Cressey, } 1991\end{array}$ \\
\hline C. herberi $=$ C. sansum & Carangidae & India & Pillai, 1963 \\
\hline C. melampygus & Carangidae & $\begin{array}{l}\text { Sri Lanka, India, } \\
\text { islands Revilla Hihedo }\end{array}$ & $\begin{array}{l}\text { Pillai, } 1963 \text { Kirtisinghe, } \\
\text { 1964; Cressey, } 1991\end{array}$ \\
\hline C. rubber & Carangidae & Belize & Cressey, 1991 \\
\hline C. sexfasciatus & Carangidae & $\begin{array}{l}\text { Taiwan, Philippines, } \\
\text { Sulawesi }\end{array}$ & $\begin{array}{l}\text { Cressey, 1991; Ho, Lin, } \\
2007\end{array}$ \\
\hline Chloroscombrus chrysurus & Carangidae & Texas & Causey, 1953 \\
\hline Decapterussp. & Carangidae & Vietnam & Present paper \\
\hline $\begin{array}{l}\text { Megalaspis cordyla } \\
\text { (=Caranx rotteri) }\end{array}$ & Carangidae & $\begin{array}{l}\text { Trincomalee (Sri } \\
\text { Lanka) }\end{array}$ & Bassett-Smith, 1898 \\
\hline $\begin{array}{l}\text { Thunnus albacare } \\
\text { (=Neothunnus macropterus) }\end{array}$ & Scombridae & $\begin{array}{l}\text { Trincomalee (Sri } \\
\text { Lanka) }\end{array}$ & Bassett-Smith, 1898 \\
\hline Lutjanus apodu & Lutjanidae & Belize & Cressey, 1991 \\
\hline $\begin{array}{l}\text { Haemulonauro lineatum } \\
\text { (=Bathystoma rimator) }\end{array}$ & Haemulidae & Jamaica & Wilson, 1913 \\
\hline
\end{tabular}

\section{A key to Caligus species from Vietnam}

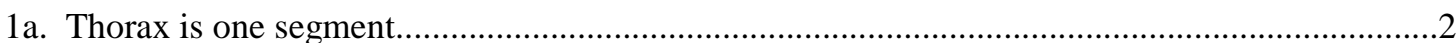

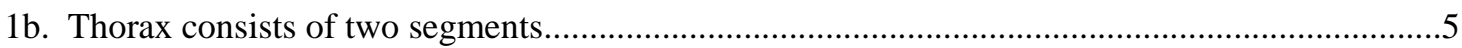

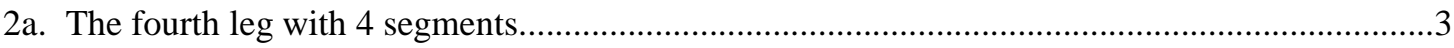

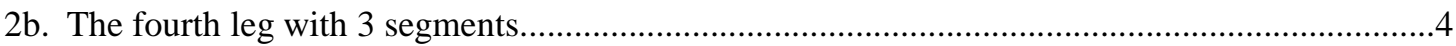

3a. Distal end of the thorax furca acuted......................................... confusus Pillai, 1961

3b. Distal end of the thorax furca blunted .................................... fortis Kabata, 1965

4a. Papilla's length of the first segment-exopodite of the second leg equaled to paplilla's length of the second segment-exopodite. C. epidemicus Hewitt, 1971

4b. Papilla's length of the first segment-exopodite of the second leg longer than paplilla's length of the second segment-exopodite. Caligus lacustris Steenstrup et Lütken, 1861 
5a. Thorax area of carapace over to posterior-field edges of carapace 6

5b. Thorax area of carapace not over to posterior-field edges of carapace and located on the posterior-field edges level.

C. constrictus Heller, 1865

6a. The thorax length less than genital complex length

C. arii Bassett-Smith, 1898

6b. The thorax length longer than genital complex length.

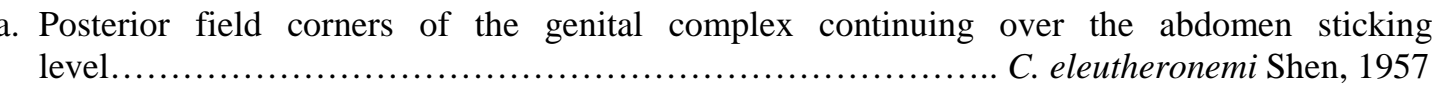

7b. Posterior field corners of the genital complex not continuing over the abdomen sticking level.. 8

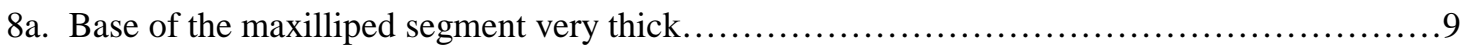

8 b. Base of the maxilliped segment not thick........................................... 10

9a. Base of the maxilliped segment with one papilla for the end of distal

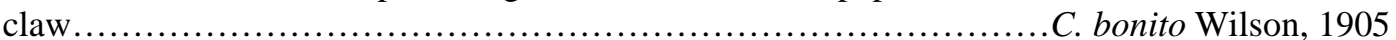

9b. Base of the maxilliped segment with two papillae for the end of distal claw. Bassett-Smith, 1898

10a. The ends of the thorax furca acuted.... C. pelamydis Krøyer, 1863

10b. The ends of the thorax furca blunted.... .C. multispinosus Shen, 1957

\section{REFERENCES}

1. Arthur J. R., Te B. Q., 2006. Checklist of parasites of fishes of Viet Nam. FAO Fisheries Technical Paper. No. 369/2. Rome, FAO. 133 p.

2. Bykhovskaya-Paulovskaya I. E., 1985. Parasites of fish. Study Guide.-Leningrad: Nauka. 121p. (in Russian).

3. Cressey R. F., Nutter P., 1987. Reidentification of David Causey's Caliguscollections (Crustacea: Copepoda). Proc. Biol. Soc. Wash., 100(3): 600-602.

4. Ho J.-S., Lin C.-L., 2004. Sea lice of Taiwan (Copepoda: Siphonostomatoida: Caligidae). Sueichan Press, Taiwan. 388 p.

5. Ho J.-L., Lin C.-L., 2007. Three species of Caligus Müller, 1785 (Copepoda: Caligidae) parasitic on Caranx spp. (Teleostei: Carangidae) of Taiwan. Syst. Parasitol., 68: $33-43$.

6. Kabata Z., 1968. Two species of Caligus (Caligidae) from New Caledonia. Crustaceana, Supp. № 1: 1-10.

7. Kazachenko V. N., Kovaleva N. N., Nguyen Vu Thanh, Ha Duy Ngo, 2013. Fish parasitic crustaaseans of Vietnam - Caligidae
(Crustace: Copepoda: Siphonostomatoida). Proceedings of the $2^{\text {nd }}$ International Scientific and Technical Conference. Vladivostok, Dalrybvtuz, 238-250.

8. Pillai N. K., 1961. Copepods parasitic on south Indian fishes. Part 1. Caligidae. Bull. Central Res. Inst. Univ. Kerala, Trivandrem, 8: $87-130$.

9. Pillai N. K., 1963. Copepods parasitic on South Indian fishes-family Caligidae. J. Mar. Biol. Ass. India, 5(1): 68-96.

10. Rangnekar M. P., 1956. Parasitic copepods from the marine fishes of Bombay. J. Univ. Bomb., 24(5): 42-65.

11. Samotylova N. N., 2010. Parasitic copepods of the family Caligidae (Crustacea: Copepoda, Siphonostomatoida) fish in Vietnam. Proceedings of the International Scientific and Technical Conference, part 1. Vladivostok: 98-99 (in Russian).

12. Samotylova N. N., 2011. Representatives Cyclopoida and Siphonostomatoida (Crustacea: Copepoda) in the fauna of Vietnam. Proceedings of the Samara Scientific Center of the Russian Academy of Sciences, 13(1): 1146-1148 (in Russian). 
13. Samotylova N. N., Kazachenko V. N., Ha Duy Ngo, Nguyen Vu Thanh, 2011. Parasitic copepod Caligus arii BassettSmith, $1898 \quad$ (Crustacea: Siphonostomatoida: Calogidae) in Vietnam marine fish. Proceedings of The $5^{\text {th }}$ Conference of Marine Science and Technology, Hanoi: 205-210 (in Vietnamese).

14. Samotylova N. N., Kazachenko V. N., Ha Duy Ngo, Nguyen Vu Thanh, 2012. Representatives of genus Hatschekia (Crustacea: Copepoda: Siphonostomatoida: Haschekiidae) in fauna of Vietnam. Proceedings of the $1^{\text {nd }}$ International Scientific and Technical Conference. Vladivostok, Dalrybvtuz, 136-138.

15. Samotylova N. N., Kazachenko V. N., Ha Duy Ngo, Nguyen Vu Thanh, 2012. New species parasitic copepods (Crustacea: Copepoda) of fishes for fauna of Vietnam.
Proceedings of the $1^{\text {nd }}$ International Scientific and Technical Conference. Vladivostok, Dalrybvtuz, 138-143.

16. Shiino S. M., $1959 . \quad$ Ostpacifische parasitieren de Copepoden. Rep. Fac. Fish. Pref. Univ. Mie., 3(2): 267-333.

17. Song D., Chen G., 1976. Some parasitic copepods from marine fishes of China. Acta Zool. Sin., 22(4): 406-424.

18. Vo The Dung, Glenn Allan Bristow, Dung Huu Nguyen, Dung Thi Vo, 2008. Parasitism of two species of Caligus (Copepoda: Caligidae) on wild and cultured grouper in Vietnam. J. Fish. Soc. Taiwan, 35(1): 35-43.

19. Vo T. D., Bristow G. A., Nguyen H. D., Vo T. D., Nguyen N. T. N., 2012. The Parasites of Grouper and Sea Bass in Vietnam. Agricultural Publishing House, Ho Chi Minh city. $178 \mathrm{p}$.

\title{
MÔ TẢ LẠI BA LOÀI GIÁP XÁC Caligus Müller, 1785 (Copepoda: Caligidae), KÝ SINH Ở LOÀI CÁ NỤC Decapterus sp. (Perciformes: Carangidae) Ở VỊNH BẮC BỘ, VIỆT NAM
}

\author{
Kazachenko V. N. ${ }^{1}$, Kovaleva N. N. ${ }^{1}$, \\ Hà Duy Ngọ ${ }^{2}$, Nguyễn Văn Hà ${ }^{2}$, Nguyễn Vũ Thanh ${ }^{2}$
}

${ }^{1}$ Trường Đại học kỹ thuật tổng hợp Quốc gia nghề cá Viễn Đông, Vladivostok, Liên Bang Nga ${ }^{2}$ Viện Sinh thái và Tài nguyên sinh vật, Viện Hàn lâm KH \& CN Việt Nam

\section{TÓM TÁT}

Bài báo này đưa ra khóa định loại cho 11 loài copepod ký sinh trên nhiều vật chủ ở Việt Nam, lần đầu mô tả lại chi tiết 03 loài giáp xác thuộc giống Caligus Müller, 1785, đó là Caligus confusus Pillai, 1961, C. constrictus Heller, 1865 và $C$. robustus Bassett-Smith, 1898, là ba loài ký sinh trong mang cá nục Decapterus sp.thu được ở vịnh Bắc bộ, Việt Nam. Đã xác định cá nục Decapterus sp. là vật chủ của các loài giáp xác ký sinh thuộc giống Caligus và là lần đầu tiên ghi nhận về sự có mặt của chúng ký sinh trên khu hệ cá biển tự nhiên Việt Nam.

Loài Caligus confusus Pillai, 1961. Con cái dạng caligoid, dài cơ thể 3,3-4,01 - 4,04 (3,53) mm. Chân ngực rộng, dẹt có màng ngoài bao quanh. Các tấm phía trước phát triển, với các hình nhỏ có dạng lưỡi liềm trên bề mặt chúng,. Chân ngực gồm I-III đốt ngực. Đốt ngực IV tự do, nhỏ và hẹp, dài $0,3 \mathrm{~mm}$. Cơ quan sinh dục gồm 2 phần với cạnh bên lồi ra. Phần đầu hẹp dạng cổ chai, phần sau với phía trước thu hẹp, phía cạnh sau song song, góc cạnh ngoài tròn hơi nhô về phía sau. Cạnh phía sau của cơ quan sinh dục hình chữ $\mathrm{V}$, nối với đốt abdomen. Abdomen nhỏ, hẹp về phần cuối và chỉ cấu tạo từ một đốt. Chạc tơ đuôi rất nhỏ, có 04 tơ vũ lớn và 02 tơ vũ nhỏ, 01 tơ trần. Túi nhận trứng đơn tính dạng hình trụ. Ăng ten I cấu tạo từ 2 đốt, gốc ăng ten với tơ vũ; đốt 2 dài. Ăng ten II gồm 3 đốt, phần cuối cùng có móng vuốt cong, với 2 tơ trên mạt bụng. Maxilla đầu phân nhánh cấp I, ở phần gốc có 2 mấu cùn với phần gốc có 03 tơ trần. Maxilla thứ II cấu tạo từ 2 đốt, dạng nhánh, phần cuối có 2 tơ vũ với kích thước không đều nhau, dạng xoắn. Maxilliped từ 3 đốt, ở trên đốt 
cuối cùng có một tơ vũ. Furka bụng với gốc oval, tách biệt song song với phần tận cùng mấu có hình dạng tròn tù, phần cuối của các mấu này nhọn. Chân bơi thứ I, có cấu tạo từ 2 đốt, chân bơi thứ II, phân thành hai thùy bánh chèo, cấu tạo từ 3 đốt, phần giữa hai thùy bánh chèo có các tơ vũ. Chân bơi thứ III phân thành 2 thùy, chân bơi thứ IV không phân thùy, có cấu tạo từ 3 đốt. Chân bơi thứ $\mathrm{V}$ thoái hóa và nằm sau góc bên bụng của hệ sinh sản với 1 tơ cứng, chân bơi thứ VI thoái hóa nằm sau góc bên bụng của hệ sinh sản với 3 to cứng.

Loài Caligus constrictus Heller, 1865. Con cái dạng caligoid, dài cơ thể 2,52-3.08 (2.80) mm. Chân ngực rộng, dẹt, được màng ngoài bao quanh. Các tấm phía trước rất phát triển, với các hình nhỏ dạng lưỡi liềm trên bề mặt chúng. Chân ngực gồm I-III đốt ngực. Đốt ngực IV tự do, nhỏ và ngắn. Cơ quan sinh dục lớn, trờm cả về phía trước và kéo dài về cạnh sau ở dạng chữ $\mathrm{V}$ nông, với chiều dài lớn hơn chiều rộng. Abdomen nhỏ, phần đầu nở và kéo về phía sau. Mút đuôi phân nhánh với 04 tơ vũ lớn, 02 tơ vũ nhỏ và 01 tơ vũ trần. Túi nhận trứng đơn tính dạng hình trụ. Ăng ten I cấu tạo từ 2 đốt, đốt gốc ăng ten với tơ vũ; đốt 2 dài. Ăng ten II gồm 3 đốt, phần cuối cùng có móng vuốt cong, với 2 tơ trên ở gốc và phần giữa mạt bụng. Maxilla đầu phân nhánh cấp I, ở phần gốc rộng có 0 mấu trên phần gốc với 03 tơ trần có chiều dài khác nhau. Maxilla thứ II cấu tạo từ 2 đốt, phần cuối có 2 tơ vũ với kích thước không đều nhau, một cái dạng xoắn. Maxilliped từ 3 đốt, ở trên gốc của đốt cuối cùng có một tơ trần. Furka bụng với gốc oval, tách biệt song song với phần tận cùng mấu có hình dạng tù, phần cuối của các mấu này nhọn. Chân bơi thứ I, có cấu tạo từ 2 đốt, chân bơi thứ II, gồm hai nhánh, thùy bơi cấu tạo từ 3 đốt, với phần gốc có các tơ vũ lớn, cuối cạnh ngoài chân bơi có các tơ vũ, phần cạnh bên trong có các tơ trần. Chân bơi thứ III có 2 thùy, chân bơi thứ IV không phân thùy, có cấu tạo từ 3 đốt. Chân bơi thứ $\mathrm{V}, \mathrm{VI}$ thoái hóa và nằm về góc bên bụng của hệ sinh sản với 02 tơ cứng.

Loài Caligus robustus Bassett-Smith, 1898 có cơ thể dạng caligoid, dài $5.47 \mathrm{~mm}$. Chân ngực rộng, dẹt, được màng ngoài bao quanh. Các tấm phía trước rất phát triển, với các hình nhỏ dạng lưỡi liềm trên bề mặt chúng. Chân ngực gồm I-III đốt ngực. Đốt ngực IV tự do, hẹp. Cơ quan sinh dục hình trái tim, thu hẹp về phía trước cơ thể. về cạnh sau ở dạng chữ $\mathrm{V}$ nông, với chiều dài lớn hơn chiều rộng. Abdomen dài, gồm 02 đốt, đốt đầu dài hơn đốt 2 , phần cuối của đốt 2 thu hẹp. Mấu đuôi phân nhánh ngắn, rộng với 04 tơ vũ lớn, 02 tơ vũ nhỏ; ở cạnh trong của mấu đuôi có tư vũ nhỏ. Túi nhận trứng hình trụ, đơn tính. Âng ten I cấu tạo từ 2 đốt, đốt gốc ăng ten với tơ vũ; đốt 2 nhỏ. Ăng ten II gồm 3 đốt, phần cuối cùng của đốt 2 có móng vuốt cong, với 2 tơ trên ở gốc, ở phía cuối cùng của vuốt phía bên bụng có 2 gai. Maxilla I gồm 2 đốt, ở phần gốc rộng có 1 mấu trên đó phủ 3 tơ trần. Maxilla thứ II cấu tạo từ 2 đốt, phần cuối có 2 gai với kích thước không đều nhau. Maxilliped từ 3 đốt, ở trên gốc của đốt cuối cùng có 2 mấu nhỏ và 1 tơ. Furka kiểu rectangular với gốc vuôngchữ nhật, tách biệt song song với phần tận cùng mấu, phần cuối của các mấu này tù. Chân bơi thứ I, có cấu tạo từ 2 đốt, chân bơi thứ II, gồm hai nhánh, thùy bơi cấu tạo từ 3 đốt, với phần gốc có các tơ vũ lớn, cuối cạnh ngoài chân bơi có các tơ vũ, phần cạnh bên trong có các tơ trần. Chân bơi thứ III có 2 thùy, chân bơi thứ IV không phân thùy, có cấu tạo từ 3 đốt. Chân bơi thứ $\mathrm{V}$, VI thoái hóa và nằm về góc bên bụng của hệ sinh sản với 04 tơ cứng

Tù khóa: Caligus, cá biển, giáp xác, vịnh Bắc bộ, Việt Nam.

Ngày nhận bài: 15-1-2014 